\title{
A 空気清浄器の除菌効果に関する検討*
}

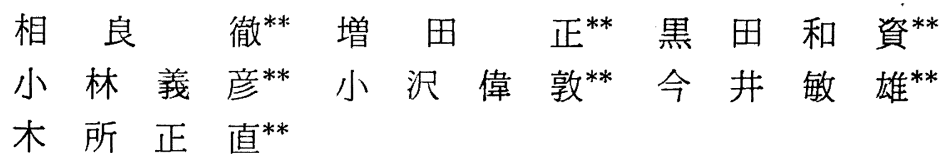

\begin{abstract}
概要：最近病院，診療所に㧍ける院内感染，製薬，食品事業関倸に招汀る細菌污染に対して，室内空 気の除菌に多大の関心が払われるよになった。そのため現在多くの空気清浄器が 開発市販されている が, 室内に持ち込みらる空気清浄器は, 除菌については, 必ずしも效果的なものばかりではない。著者 らは今回, A 空気清浄器本体の空気取り入れロ及び排出口の両側に, 内容 $1.11 \mathrm{~m}^{8}$ の箱 $\mathrm{B}$ を取り入れ口 侧に, 内容 $0.87 \mathrm{~m}^{3}$ の箱 $\mathrm{C}$ を排出口側に密着して接続した。箱 $\mathrm{B}$ の前面上にガラス製, $0.3 \mu$ 飛沫粒子 を散布しうる nebulizer を取り付けこの nebulizer に trypto-soy broth $(30 \mathrm{~g}$ を $2000 \mathrm{ml}$ に加温 溶解滅菌）培羕液中に serratia marcescens 菌を $182 \times 10^{6}$ 個 $/ \mathrm{ml}$ 上したものを箱 B内に噴嚯し，A清浄 器を作動させ箱 $\mathrm{B}$ の吸引口と, 箱 Cの排出口の所で, SY 式 pin hole Sampler で菌を捕集した。測定 時の風量はメインスイッチのI $\left(8.7 \mathrm{~m}^{3} / \mathrm{min}\right)$, II $\left(9.1 \mathrm{~m}^{3} / \mathrm{min}\right)$, III $\left(9.9 \mathrm{~m}^{3} / \mathrm{min}\right)$, で行なった。また 本清浄器に内臟されている, フィルター, 特殊フィルター, 活性炭, 殺菌燈の各機構部分を本体から取 り出し，それぞれ単独に本体内に設置してそれぞれについて除菌に対する性能を測定した。(1) serra-

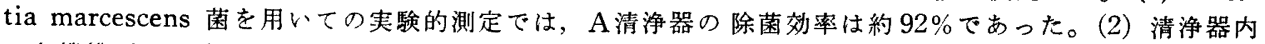
の各機構ごとの除菌勃果は電気集塺器が大きく $86.7 \%$, 次がフィルターで $45.7 \%$, 殺菌燈では約 $18.7 \%$ であった。(3) 殺菌燈のみでの除菌効果は内部の各機構を脱却した場合の除菌効率 $17.6 \%$ とほぼ同様で あることから，殺菌燈の効果は殆んどみられていないと考えられる。(4) 本器に用いられたフィルター では約 $45 \%$ の除菌率であった。除菌後の清浄器内の殺菌についても充分考虑することが必要である。
\end{abstract}

\section{緒言}

最近病院，診療所における院内感染1,2,3製薬，食品事 業関倸における細菌污染に対して, 室内空気の除菌に多 大の関心が払われるようになった4,5)。一般に室内空気 中の除菌は, 所謂パーツとして, 空気調整器6) や紫外線 あるいはオゾン殺菌》を用いての装置が用いられてい る。現在多くの空気清浄器が開発市販されているが, 室 内に持ちこみうる空気清浄器は, 簡易に使用しうる便利 さはあるが，その効果，特に除菌については，必ずしも 効果的なものばかりではなく，一様な成績を示すもので

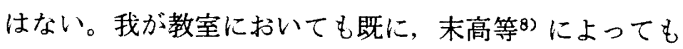
基䃈試験がおこなわれている。著者らは今回, $\mathrm{A}$ 空気清
浄器についての除菌効果を測定する機会を得たので報告 する。

\section{被検 $\mathbf{A}$ 空気清浄器の構造及び測定方法}

1) 構造 $\mathrm{A}$ 空気清浄器の構造は, 図 1, 表 1 の如く である。上面に横 $66 \mathrm{~cm}$, 縦 $27 \mathrm{~cm}$ の空気取り入れ口 a. (取 り入れ口 a が使用不可能な際に使用するために, 裹面に 取り入れ口 bがある。b は通常は密閉されている。）前 面の高さ $129.6 \mathrm{~cm}$ の位置に横 $60 \mathrm{~cm}$, 縦 $17 \mathrm{~cm}$ の吹出し グリル c がある。内部機構は図 2,3 亿示した如く, プ レフィルター, 電気集鷹器, 殺菌燈 $(10 \mathrm{~W} \times 1)$, イオ ン交換樹脂フィルター, 活性炭フィルター, アフターフ イルター, (一) イオン 発生器等が順次内臟され, 取り

* 第25回日本大学歯学会総会において口頭発表

* 昭和 48 年 5 月 12 日

** 日本大学歯学部衛生学教室 (主任: 木所正直教授)

* Department of Hygiene and Dental Public Health, Nihon University School of Dentistry, Tokyo. (Director: Prof. Masanao KIDOKORO)

昭和51年 7 月 12 日受付 


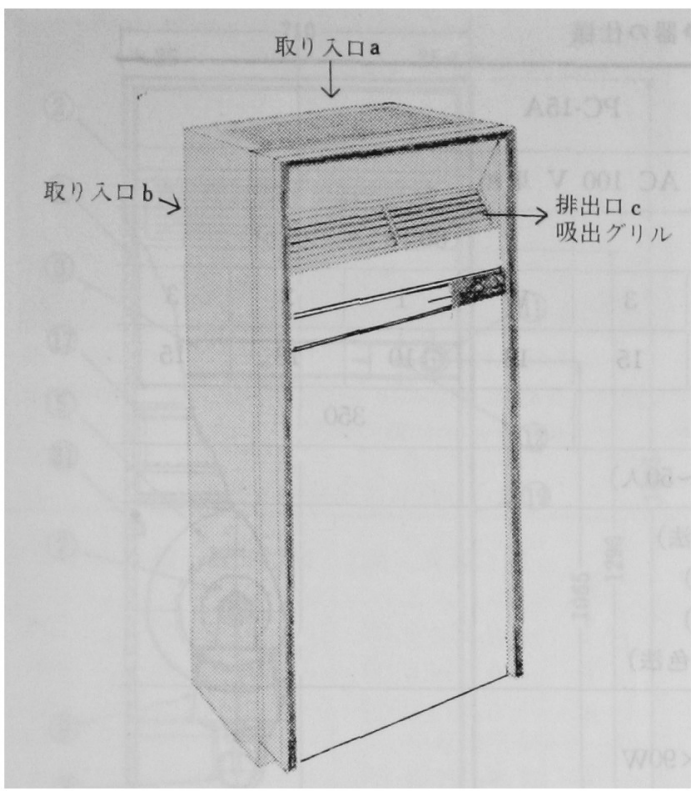

図 1 A 空気清浄器の外観

入れ口 a からはいった室内空気はこれを通過し除菌され る機構であり, AC 100V, $250 \mathrm{~W}, 50 \mathrm{cycle}$ で運転され 室内の状況により, メインスイッチの I で風量 $10 \mathrm{~m}^{3} /$ $\min$, II で $13 \mathrm{~m}^{3} / \mathrm{min}$, III 用しうるようになっている。本器の性能は $48 \sim 80 \mathrm{~m}^{2}$ の 床面積に扔いて， $\mathrm{SO}_{2} 90 \% ， \mathrm{NO} 75 \% ， \mathrm{NO}_{2} 80 \%$ 以 上，塵埃 $90 \%$ 以上の捕集効果を示すとしているが除菌効 果については示されていない。

2）測定方法 A空気清浄器の效果を判定するには, 測定に当って資料とする空気中細菌の条件を一定の状態 のものでおこならことが必要であると考えたので，図 $4,5,6$ の如く, A 空気清浄器本体の空気取り入れ口 及び排出口の両側に, 内容 $1.11 \mathrm{~m}^{3}$ の箱 B を取り入れ口 側に, 内容 $0.87 \mathrm{~m}^{3}$ の箱 $\mathrm{C}$ を排出口側に密着して接続し た。箱 B，Cは厚さ $0.6 \mathrm{~cm}$ のベニヤ板に内面はビニー ルを貼布し，鉄製の骨格を用いて作成し，外気の侵入し ない密な箱とした。箱 Bには前下方に本体の吸引口と同 面積の空気取り入れ口を設けた。箱 Cには排出口と同面 積の開口部を下部に位置して設けた。箱Bの前面上部に ガラス製 $0.3 \mu$ の飛沫粒子を散布しらる nebulizer を取 り付け, この nebulizer に trypto-soy broth (30 g を $2000 \mathrm{ml}$ に加温溶解滅菌）培養液中に serratia marcescens 菌を $182 \times 10^{6}$ 個 $/ \mathrm{ml}$ としたものを箱 $\mathrm{B}$ 内に噴霧 し, 箱 $\mathrm{B}$ 内の空気を清浄器を作動せしめて, 箱 $\mathrm{C} に$ 排出 せしめた。菌液の箱 B内人の噴霧は $1.7 \mathrm{ml} / \mathrm{min}$ の速さ
で噴霧するごとく，歯科用コンプレッサー（100 V, 400 $\mathrm{W}$ ，回転数1430/回min）を用いておこなうた。空気清浄 器の吸引口は吸引口 a 用いた。箱 $\mathrm{B} に$ 噴霧した菌の aerosols が平等に浮遊し, 直ちに落下寸ることを防ぐた めに, 扇風器 $(100 \mathrm{~V}, 33 \mathrm{~W}$, 風速 $150 \sim 176 \mathrm{~m} / \mathrm{min}$, 渢量 $14 \sim 18 \mathrm{~m}^{3} / \mathrm{min}$ ) を用いて下から上方に向って送風し た。空気中細菌の捕集は図 7 に示す SY 式 pinhole sampler ${ }^{9,10)}$ を用いた。SY 式 pinhole Sampler は上部に 内径 $3 \mathrm{~cm}$ の空気取り入れ口がある。その中に直径 1 $\mathrm{mm}$ の Slit が等間隔に 5 個並び, その Slitより外気 を吸引する。Slit の下には 2 分間で 1 回転するターン テーブルがあり，その上にシャーレを置き空気中細菌を 捕集する。Slit と培地の間隔は $2 \mathrm{~mm}$ に調節できるよ らになっており, 吸引ポンプで50 $55 \mathrm{l} / \mathrm{min}$ の空気を吸 引する。図 8 は本装置で Serratia marcescens 菌を捕 集したもので, 左は空気清浄器の通過前, 右が通過後で ある。箱 B内の細菌の捕集は, 図 4, 5 に示すごとく, 吸引口 a に接近した位置にビニール管（直径 $3.8 \mathrm{~cm}$, 長 さ40 cm)を用いて，これを SY 式 pinhole sampler ${ }^{9,10)}$ に接続して行なった。清浄器を通過した空気からの細菌 の捕集は図 6 に示す如く, 排出口において, 箱 B の場合 と同様な方法で採取した。何れの場合も 1 回にシャーレ 3 枚宛を用い, trypto-soy 寒天培地で $31^{\circ} \mathrm{C}, 72$ 時間培 盖後のコロニー数を算定した。捕集後の排出空気は, 図 6 に示寸如くビニール風洞を径て排出せしめた。尚, 排 出には安全を期するため風洞内で70\%アルコール液を噴 霧し排出した。今回は清浄器本体の両側に箱 $\mathrm{B}, \mathrm{C}$ を取 りっけておこなったことから, 室内に拀ける場合とは風 量がやや異なることが考えられるので測定時の風量を測 定した結果, メインスイッチの I では $8.7 \mathrm{~m}^{3} / \mathrm{min}$, II で は $9.1 \mathrm{~m}^{3} / \mathrm{min}$, IIIでは $9.9 \mathrm{~m}^{3} / \mathrm{min}$ であったので, 全ての 測定はこの 3 段階に合致させておこなった。また本清浄 器に内臓されている, フィルター（プレフィルターとア フターフィルター), 特殊フィルター（金属網フィルタ 一と特殊化学フィルター), 活性炭, 殺菌燈の各々の除 菌に対する性能を見るために, 各機構部分を本体から取 り出し, 改めてそれぞれを単独に本体内に設置して, 前 回と同様の方法で測定した。以上の測定に当っては実験 室内の空気中雑菌を可及的に少なくするために, 測定開 始前に, 室内を70\%アルコール噴霧し実施消毒をおこな い, 1 時閒後に測定を開始した。

\section{成 績}

1）測定開始前 あらかじめ70\%アルコール液を噴霧 
表 1 A 空気清浄器の仕様

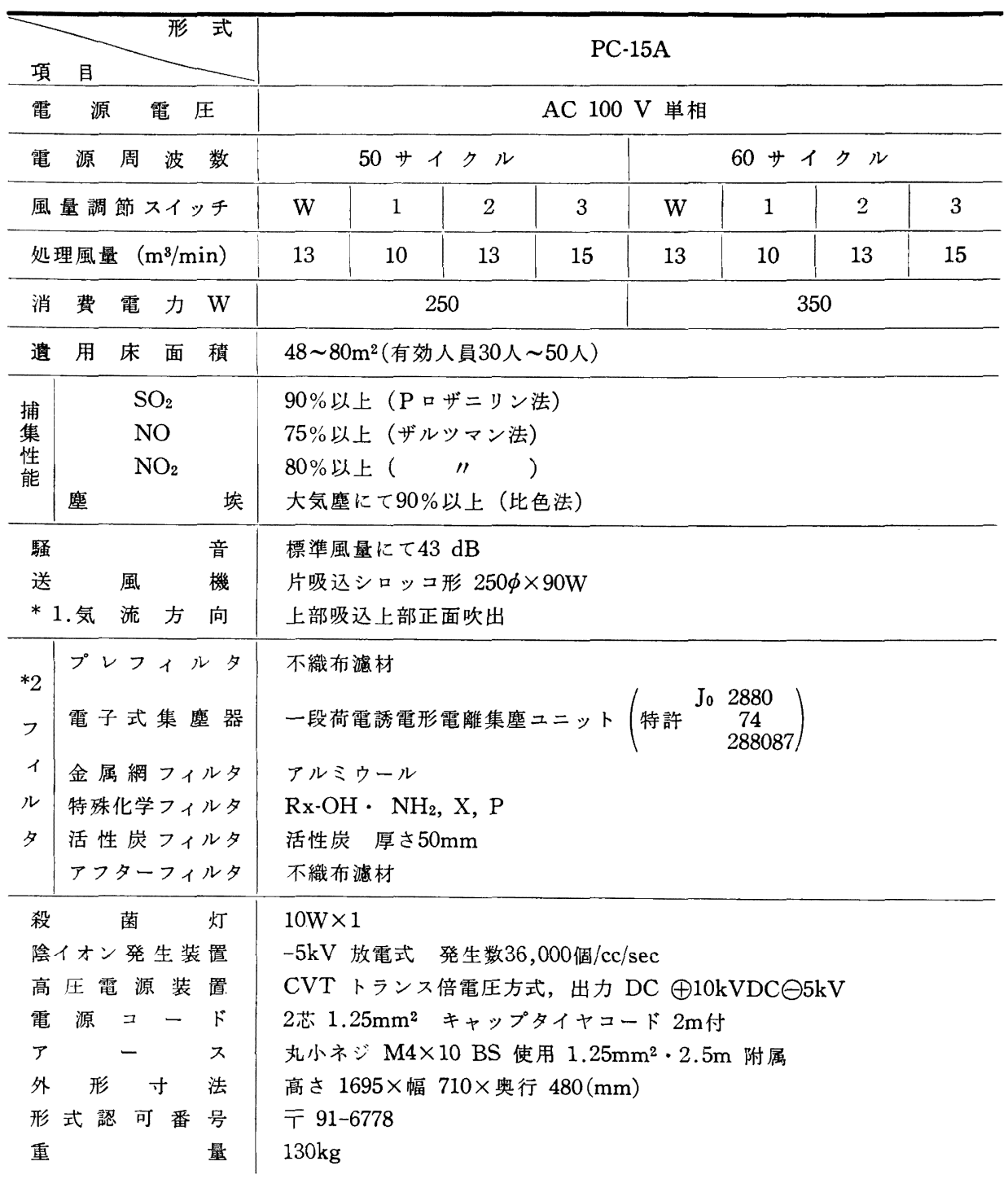

し消毒後の空気中の細菌コロニー数は表 2 亿示す如く, 雑菌0.21個/1 コロニーであったが，A空気清浄器を通 過した排出空気中の細菌コロニー数は，風量 I，II，III の何れも認められなかった。

2）箱 B内に Serratia marcescens 菌を噴霧した場 合に扔ける除菌効果は表 2 に示寸如くで，風量 I では吸 引口側で8.3個/1 コロニーが排出口側では 0.53 個/1 であ り，II では吸引口側 9.00 個/1 で, 排出口側は 0.70 個/l, IIIでは吸引口側 9.43 個/1 で排出口側0.79個/ 1 となり, 除去率は I で93.7， II で92.2，IIIで91.6\%であり，風量 の小さい方にやや勃率が大きい傾向を示した。
3） $\mathrm{A}$ 空気清浄器内部の機構のそれぞれの除菌効果は 表 3 の如く, フィルターでは44.8 46.2\%, 電気集塺器 では84.9 88.2\%, 活性炭で $28.9 \sim 30.7 \%$, 特殊フィル ターでは $31.2 \sim 36.0 \%$ ，殺菌登では16.9 20.7\%であ り,さらにこれらの機構を全て除いた場合について同様 の実験を行なった 結果 $17.5 \sim 18.7 \%$ の 除菌効果を示し た。それぞれの除塺，除菌機構を取り去ったにも拘ら ず，約 $18 \%$ の減少を示したことは恐らく本体の内面に菌 が付着したものと考えられる。 


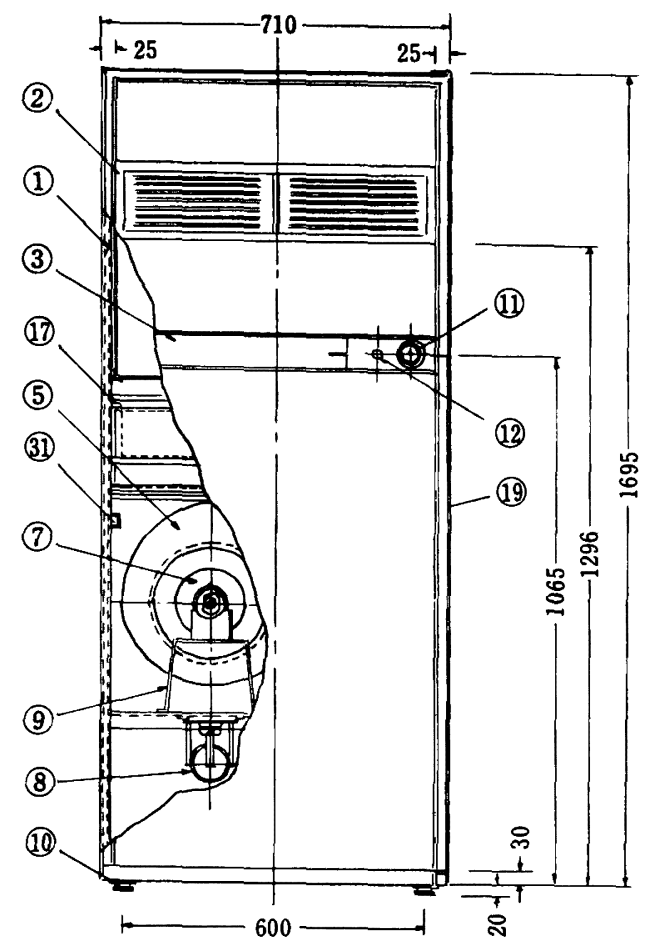

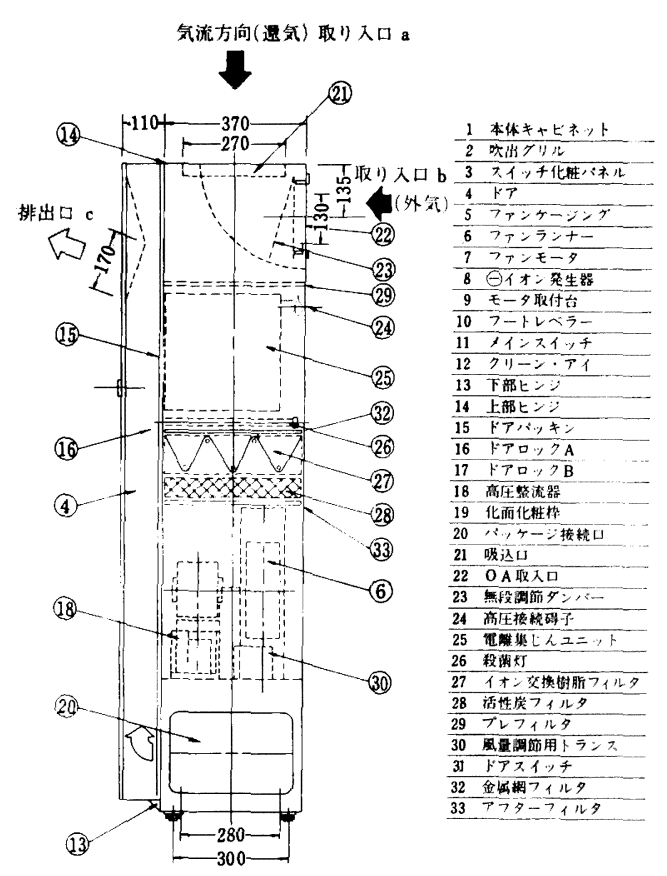

図 3 A 空気清浄器の各部名称 (2)

図 2 A 空気清浄器の各部名称 (1)

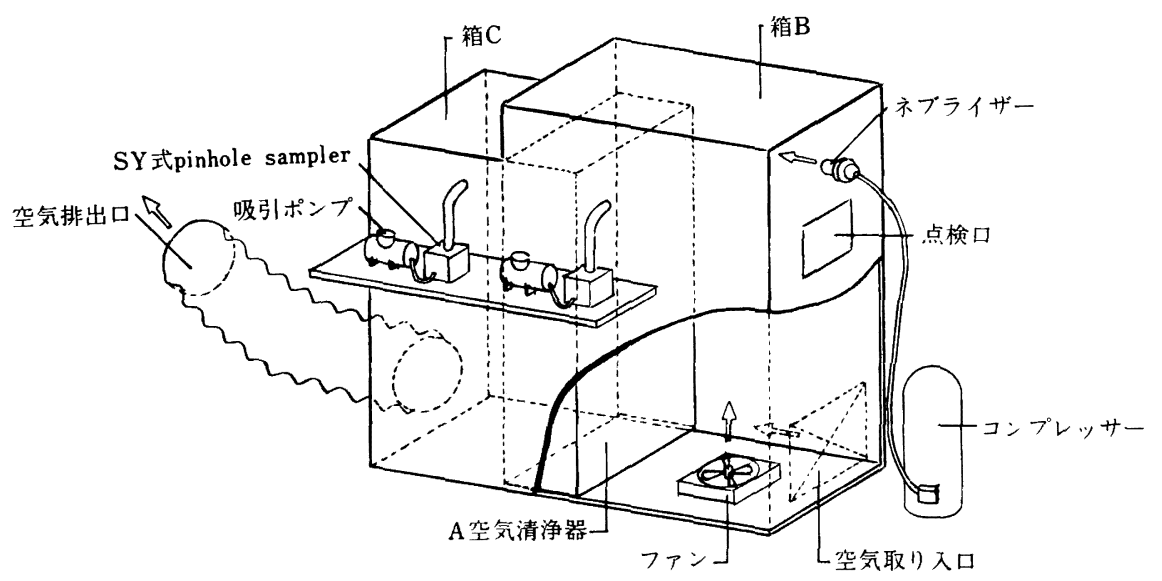

図 4 実験装置の外観

\section{考察及び結論}

空気中細菌の測定に関してはこれまで定性的なものと 定量的なものについて種々の方法がおこなわれている が，定量的に一定の方法で筀気 11 中何個といった基準 は，いまだ確立されていない。従来から落下法 ${ }^{11)}$, 滤過 法12,18,14)など多く用いられてきたが，最近は Slit sam. pler 法 ${ }^{15)}$, Andersen sampler 法 ${ }^{16)}$ などが用いられて いる。落下法は気流の影響を受けやすく定量的には確実 でない。また落下菌と浮遊菌との関係についても明らか とはなしえない。glutamic acid filter 法12,18), inpinger 法14) 等の濾過法は取り扱いによっては種々の問題 があり，技術的面に拉いても修練を要する等のことがあ る。Slit sampler 法 ${ }^{15)}$ は操作は簡単で捕集効果も良好 


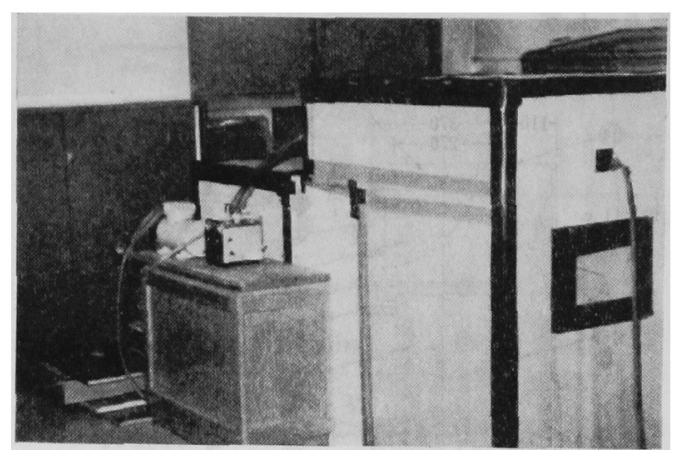

図 5 実験装置（箱 B)

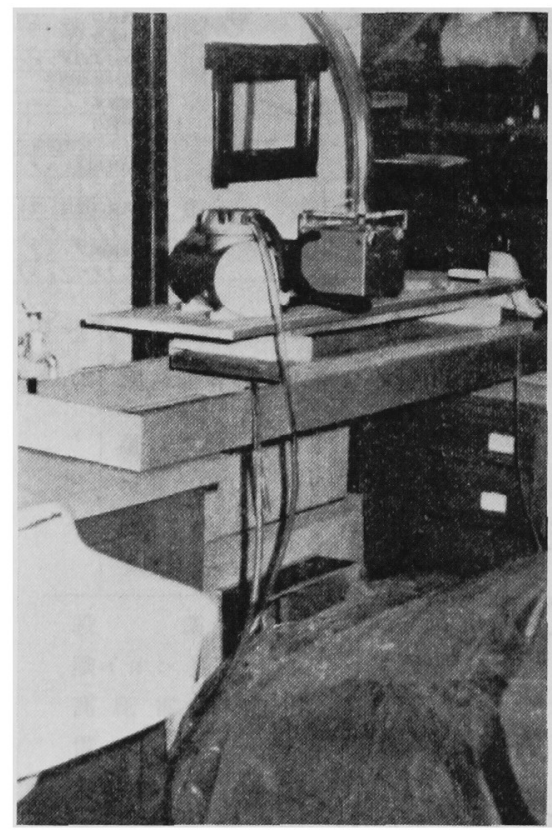

図 6 実鮕装置 (箱 C)

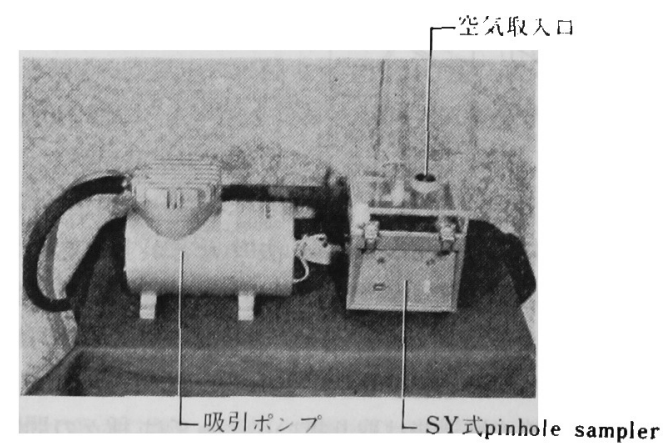

図 7 SY 式 pinhole sampler

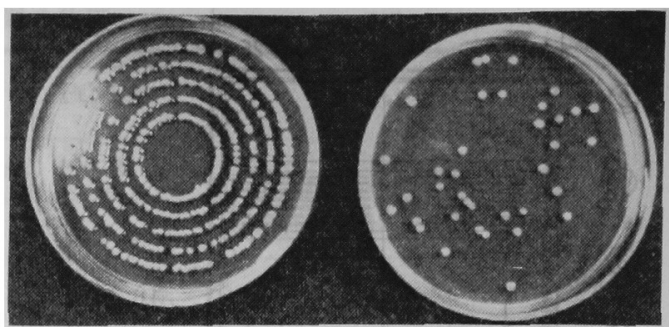

左吸込み口側

右排出口側

図 8 SY 式 pinhole sampler による serratia marcescens 菌の捕集

表 2 空気清浄器の除菌効果

\begin{tabular}{|c|c|c|c|c|}
\hline & 風量 & 吸引口側 個/l & 排出口側 個 $/ l$ & 除去率\% \\
\hline \multirow{3}{*}{$\begin{array}{l}\text { 外 } \\
\text { 気 } \\
\text { を } \\
\text { 通 } \\
\text { 過 }\end{array}$} & I & $0.21 \pm 0.02$ & $0.00 \pm 0.00$ & 100 \\
\hline & II & $0.20 \pm 0.03$ & $0.00 \pm 0.00$ & 100 \\
\hline & III & $0.19 \pm 0.02$ & $0.00 \pm 0.00$ & 100 \\
\hline \multirow{4}{*}{$\begin{array}{l}\text { 菌 } \\
\text { を } \\
\text { 散 } \\
\text { 布 }\end{array}$} & I & $8.35 \pm 0.44$ & $0.53 \pm 0.08$ & 93.7 \\
\hline & II & $9.00 \pm 0.03$ & $0.70 \pm 0.02$ & 92.2 \\
\hline & III & $9.43 \pm 0.05$ & $0.79 \pm 0.03$ & 91.6 \\
\hline & & $M \pm S . D$ & $M \pm S . D$ & \\
\hline
\end{tabular}

測定時の温度及び湿度

温度 $\cdots 22^{\circ} \mathrm{C} \sim 23 \mathrm{C}$ 湿度 $\cdots \cdot 56 \% \sim 60 \%$

であるが，器具の重量がやや大きく，操作時に音が高 く, 高価である等の難点がある。Andersen sampler 法 ${ }^{16)}$ は菌を大きさ別に採集することができるが操作がか なり複雑であり，これも高価である。そこで今回の測定 には操作が比較的簡単で，持ち運びが容易で補集効率の 高い SY 式 pinhol Sampler 法9,10) を用いた。空気清 浄器の重要な条件の一つは除菌効果の大きなことであ る。今回 A空気清浄器の除菌効率についての基礎的な測 定を実施した結果，(1)，今回の Serratia marcescens 菌を用いての実験的測定においては，A空気清浄器の除 菌效率は約 $92 \%$ であった。(2) 清争器内の各機構ごとの 除菌効果は電気集塵器が最も大きく $86.7 \%$, 次がフィル ターであり $45.7 \%$ ，殺菌燈では約 $18.7 \%$ あ゙あっ。(3) 殺菌燈のみでの除菌効果は内部の各機構を脱却した場合 の除菌高率 $17.6 \%$ とほぼ同様であることから，殺菌燈の 効果は殆んどみられていないと考えられる。(4) 本器に 用いられたフィルターでは約45\%の除菌率であったが absolute filter を用いれば99.99\%の除菌効率があると いわれているが17,18)，抵抗が大となることから用いられ ていない。今後, 更に効率を向上せしめることが必要で あるが, 同時に除菌後の清浄器内における細菌に対する 殺菌についても充分考虑することが必要であろう。 
表 3 空気清浄器の各部における除菌効果

\begin{tabular}{|c|c|c|c|c|}
\hline & 量 & 吸引口側 個 $/ l$ & 排出口側 個/l & 除去率：。 \\
\hline \multirow{3}{*}{$\begin{array}{l}7 \\
1 \\
ル \\
タ \\
1 \\
\end{array}$} & I & $8.03 \pm 0.21$ & $4.31 \pm 0.09$ & 46.3 \\
\hline & II & $8.27 \pm 0.09$ & $4.45 \pm 0.12$ & 46.2 \\
\hline & III & $8.57 \pm 0.08$ & $4.73 \pm 0.19$ & 44.8 \\
\hline \multirow{3}{*}{$\begin{array}{l}\text { 集 } \\
\text { 應 } \\
\text { 器 }\end{array}$} & I & $7.90 \pm 0.11$ & $0.93 \pm 0.05$ & 88.2 \\
\hline & II & $8.29 \pm 0.13$ & $1.08 \pm 0.09$ & 87.0 \\
\hline & III & $8.65 \pm 0.14$ & $1.31 \pm 0.10$ & 84.9 \\
\hline \multirow{3}{*}{$\begin{array}{l}\text { 活 } \\
\text { 性 } \\
\text { 炭 }\end{array}$} & I & $8.04 \pm 0.21$ & $5.57 \pm 0.27$ & 30.7 \\
\hline & II & $8.42 \pm 0.10$ & $5.99 \pm 0.43$ & 28.9 \\
\hline & III & $8.94 \pm 0.18$ & $6.25 \pm 0.26$ & 30.1 \\
\hline \multirow{3}{*}{$\begin{array}{r}\text { 特 フ } \\
\text { 殊 } 1 \\
\text { ル } \\
\text { タ } \\
1 \\
\end{array}$} & I & $8.55 \pm 0.05$ & $5.49 \pm 0.16$ & 35.8 \\
\hline & II & $8.78 \pm 0.11$ & $5.62 \pm 0.07$ & 36.0 \\
\hline & III & $9.01 \pm 0.15$ & $6.20 \pm 0.22$ & 31.2 \\
\hline \multirow{3}{*}{$\begin{array}{l}\text { 殺 } \\
\text { 菌 } \\
\text { 燈 }\end{array}$} & I & $8.29 \pm 0.10$ & $6.89 \pm 0.14$ & 16.9 \\
\hline & II & $8.56 \pm 0.11$ & $6.79 \pm 0.15$ & 20.7 \\
\hline & III & $8.90 \pm 0.10$ & $7.25 \pm 0.23$ & 18.5 \\
\hline \multirow{4}{*}{$\begin{array}{l}\text { 完 } \\
\text { 全 } \\
\text { 脱 } \\
\text { 却 } \\
\text { 時 }\end{array}$} & I & $8.21 \pm 0.18$ & $6.77 \pm 0.16$ & 17.5 \\
\hline & II & $8.61 \pm 0.10$ & $7.10 \pm 0.06$ & 17.5 \\
\hline & III & $8.88 \pm 0.11$ & $7.22 \pm 0.29$ & 18.7 \\
\hline & & $\mathrm{M} \pm \mathrm{S} . \mathrm{D}$ & $\mathrm{M} \pm S . \mathrm{D}$ & \\
\hline
\end{tabular}

測定時の温度及び湿度

温度 $\cdots 22^{\circ} \mathrm{C} \sim 23^{\circ} \mathrm{C} \quad$ 湿度 $\cdots 56 \% \sim 60 \%$

\section{参考文献}

1）土屋俊夫：院内感染, Modern media, 18 ; 1-4, 1972.

2）坂部考：外科領城における院内感染 Modern media, $18 ; 5-6,1972$.
3）茂田士郎（他）: 病院における緑膿菌感染の実態, 臨床病理, 18(12)；885-888.

4）笠井金盛：食品製造工程に掞ける衛生基準，食 品機械装置，7(1)；93-99，1970.

5）住江金之：食品の污染と返品防止対策, 食品開 発, 6(1)；16-18，1971.

6) 斎藤平蔵: 病院の空気設備について, 空気調和, 衛生工学, 44(8)；696-710, 1970.

7）滝沢邦去：食品工場における殺菌燈の利用と効 果, New Food. Industry. 8(6)；12-16, 1966.

8) 末高武彦(他)：空気清浄器の清浄効果に関する 研究. 日大歯学, 42(2)；142-147, 1968.

9）山崎省二：空中浮遊菌の测定法. 日本細菌学会 第23回大会要旨, 1968.

10）山崎省二：空中細菌について, 衛生院研究愍談 会記事, $1970,4,28$.

11) 日本薬学会編: 衛生試験法注解, 金原出版, 1969.

12）佐野信男：空中細菌の一定量的検査法, グルタ ミン酸ソーダーによる捕菌器について(第一報) 大阪大学医学雑誌, 6(1);34-42, 1953.

13) Millipore Catalog $\mathrm{MC} / 1,2 \mathrm{~B} 080$, Millipore. Corporation Masachasetto.

14）吉沢晋：浮遊細菌の測定法(匴議集より)，1966, 6, 18.

15) R. B. Bourodillon, et al.: A \& lit Sampler for Collecting and Counting Airborne Bacteria. Journal of Hygiene. 41(2); 197-224, 1941.

16) Ariel A. andersen: New Sampler for the Collection, Sizing and Enumeration of Viable Airbone Particles Journal of Bacteriol. 76 ; 471-484, 1958.

17) H. M. Decker, et al., 訳者 井上宇市 : Air Filtration of Microbial particles. 病院設備, 8(4) ; 19-38, 1966.

18）井上宇市：病院などに扮けるバイオクリーンの 技術, 医学誌, 42(6)；390-414, 1972. 
Abstract: A Study on the Effect iveness of the Elimination of Bacteria by an A-Type Air Purifier, Tohru SAGARA*, Tadashi MASUDA*, Kazusuke KURODA,* Yoshihiko KOBAYASHI*, Hidetoshi OZAWA*, Toshio IMAI* and Masanao KIDOKORO*. In view of the intramural infection at the hospitals and clinics and the bactrial pollution of foods and pharmaceuticals in recent years, much attetion has come to be paid to the elimination of bacteria from the air inside the rooms.

For this reason, there are commercially available many types of air purifiers, but not all the purifiers which can be placed inside the room are effective in eliminating air-borne bacteria.

In the present study, the authors concerned themselves with bacterial elimination by means of an A-Type air purifier.

For our experimental purposes, an inlet box (B) of $1.11 \mathrm{~m}^{3}$ in content and another box (C) of $0.87 \mathrm{~m}^{3}$ were respectively attached to the inlet and outlet sides of this A-Type air purifier. A nebulizer made of glass, which was capable of spraying the fine $0.3 \mu$ particles was installed in front of the box (B) and, by means of this nebulizer a bacterial strain, Serratia marcescens, per $182 \times 10^{6} / \mathrm{ml}$, which was cultivated in a trypto-soy broth (in which $30 \mathrm{~g}$ was dissolved in heated water and sterilized to make $2,000 \mathrm{ml}$ ), was sprayed inside the box (B) and by activating the A-Type air purifier the bacteria were caught at two places, i.e., i) the suction inlet of the box (B) and ii) the outlet of the box (C) by use of an SY pinhole sampler.

For measurement purposes, three different wind velocities of $8.7 \mathrm{~m}^{3} / \mathrm{min}$ (main switch I), $9.1 \mathrm{~m}^{3} / \mathrm{min}$ (main switch II) and $9.9 \mathrm{~m}^{3} / \mathrm{min}$ (main switch III) were used. Moreove, the filter, special filter, activated carbon and sterilized bacterial container, which were the components of the furifier, were taken apart separately and each of them was subjected to careful examinations to measure the effect of bacterial elimination on these parts.

As a result of the present study, the authors arrived at the following conclusions :

1. In an experimental study with the use of Serratia marcescens, the amount of bacterial elimination by an A-Type air purifier was about $92 \%$.

2. Of various the components of the air purifier studied, the electrical dust collector had the highest effectiveness, $86.7 \%$, followed in order by the filter with $45.7 \%$ and the sterilizing lamp with $18.7 \%$.

3. Since the effect of the sterilizing lamp was more or less similar to the $17.6 \%$ effectiveness when all the other inside components were removed, the effect of the sterilizing lamp alorie was far from adequate.

4. The filter installed in the present air purifier was $45 \%$ effective in eliminating bacteria.

It is necessary after removing the bacteria from the air, to give due consideration to the disinfection of the bacteria still remaing inside the purifier. 